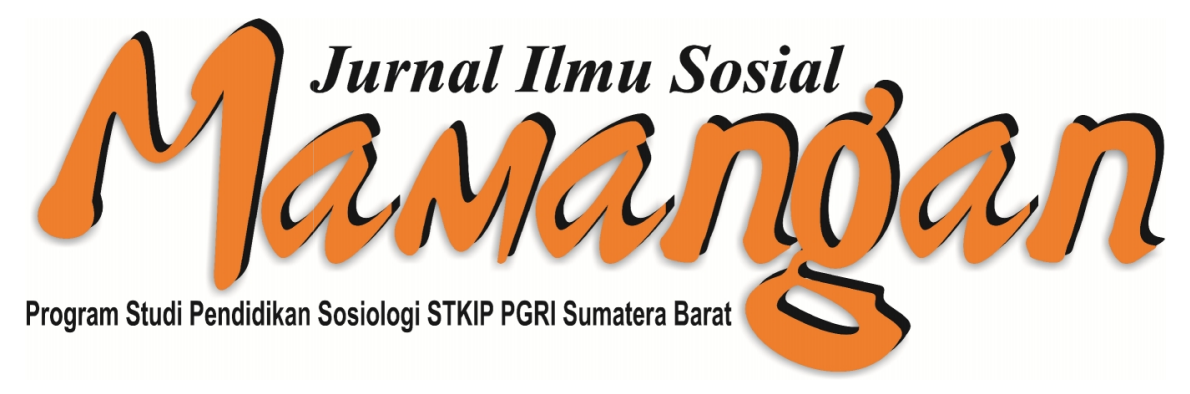

Jurnal Ilmu Sosial Mamangan

Volume 6, Number 2, July-December 2017

The Model of Community Learning Center Development: A Case Study of PKBM Assolahiyah in West Java Province

Author : Ferdinal Asmin

Source $\quad$ : Jurnal Ilmu Sosial Mamangan, Volume 6, Number 2, July-Desember 2017

Published by : Laboratorium Pendidikan Sosiologi, STKIP PGRI Sumatera Barat

To Cite the Articel:

Asmin, Ferdinal, 2017. The Model of Community Learning Center Development: A Case Study of PKBM Assolahiyah in West Java Province. Jurnal Ilmu Sosial Mamangan, Volume 6, Number 2, July-December, 2017: 61-70.

Copyright (C) 2017, Jurnal Ilmu Sosial Mamangan ISSN : 2301-8496 (Print), ISSN : 2503-1570 (Online) 


\title{
The Model of Community Learning Center Development: A Case Study of PKBM Assolahiyah in West Java Province
}

\author{
Ferdinal Asmin \\ Environmental and Natural Resources Management, Graduate School of Bogor \\ Agricultural University, Indonesia \\ Email : ferdinalasmin76@yahoo.com
}

\begin{abstract}
Sustaining community learning center (CLC) as a community activity centerby increasing the community capacity and skill to deal with socio-economics challenges is an important focus to ensure the success of CLC. This study was aimed to describe the sustainability elements of CLC development and analyze the policy elements that influence the sustainability of CLC program, particularly in related to CSR program. This study approach was combining a qualitative approach and quantitative approach with analytic decision method which is never conducted in the previous studies on CLC. Data and information were collected through document studies, observations and structured interviews through questionnaires, then they were analyzed using descriptive analysis and interpretive structural modeling (ISM) analysis. From ten elements of CLC sustainability were analyzed, the result of study emphasized to the importance of CLC management capacity enhancement in PKBM Assolahiyah. The result was synthesized into a policy model of CLC development through CSR program. The policy model should involve the roles of government, scientist, and non-governmental organization (NGO) to strengthen the CLC development.
\end{abstract}

Keywords : corporate social responsibility, management capacity, policy model, sustainability

\section{INTRODUCTION}

The idea for community based learning in Indonesia came from World Declaration in the theme "education for all" in 1990 which was declared in Jomtien, Thailand. The declaration aimed to develop a concept of community learning center. The implementation of that idea was just realized by Indonesian Government through the Ministry of Education and Culture in 19971998 with a program named Pusat Kegiatan Belajar Masyarakat (PKBM) or known as community learning center (CLC). The existence of CLC in Indonesia was then recognized as a form of non-formal education as mentioned in Article 26 Section (4) of Indonesian Act Number 23 the Year 2003 on National Education System.

CLC is a community based institutioncome from, established by, and developed for the community itself which aims to encourage the progress and empowerment of community life (Dirbindikmas, 2012:4). The main program of CLC in Indonesia includes literacy, early childhood education (known as PAUD), equality education, vocational training, entrepreneurship training, sports and recreation, and women education. CLC which was supported by the government can 
decrease the illiteracy level in Indonesia. However, the government interventions could also lead in sufficient programs with the specific needs and resources of the community, including labor market needs. Even, the interventions could increase the community dependence to the government programs (UNESCO, 2008:43). Furthermore, for CLC sustainability. UNESCO (2011:34) suggested to encourage the strengthening of "step-father" system, but only for a technical management assistance.

To ensure the CLC sustainability, some programs of corporate social responsibility (CSR) should be encouraged to provide an assistance in strengthening the CLC. According to Rionda's definition written for CATALYST Consortium, an organization funded by USAID, CSR refers to transparent business practices that are based on ethical values, compliance with legal requirements, and respect for people, communities, and the environment (Rionda 2002:2). People and communities include employers, customers, business partners, investors, suppliers and vendors, the government, and the community. CSR is also a form of real concern from business corporations to sustain the environment (Herlina, Oktavia, \& Elvawati, 2014:11). Based on the concept, CSR could be directed to support the CLC sustainability around the company's location.

The CLC sustainability as a center of community activities in developing their capabilities and skills to overcome the socioeconomic challenges is an important policy focus ensuring the CLC success. UNESCO (2011:32) revealed two variables of CLC sustainability, i.e. the relevance of the learning services offered to the community needs and the availability of resources needed to produce those relevant services. From two variables of CLC sustainability, this paper emphasized on the availability of resources needed to produce the learning services because this variable is affected by many internal and external factors. This paper described the development policy of CLC in related to the implementation of CSR programs for supporting the CLC.

This study is important because the CLC development in Indonesia are generally initiated by local people that were often constrained by their ability to survive and adapt with environmental changes (UNESCO,
2008:47). Research reports from other countries in Asia also recommended the government policy support and other stakeholders participation to ensure the CLC sustainability (UNESCO, 2008:13-106). Moreover, the CLC development research is needed to offer the policy recommendations for ensuring the CLC sustainability, including through CSR programs.

This article will describe the CLC development and elaborate the supporting elements for the CLC sustainability and analyze the policy elements that affect the CLC sustainability. This analysis also aimed to determine the key element, relationship structure among elements, and categorization each element in CLC development using interpretive structural modeling (ISM).

\section{METHODS}

This study useda qualitative approach witha case study of PKBM Assolahiyah inPasirjaya Village, Cilamaya Kulon SubDistrict, Karawang District, West Java Province. PKBM Assolahiyah is one of CLC in West Java Province supported by CSR program from PT Pertamina (a public company in the energy sector). The study method was also combined with a quantitative approach using analytical decision-making method. This study was held from December 2014 to January 2015. Collecting data and information was conducted by document studies, structured interviews, and field observations. Document studies involve some reviews to CLC reports and regulations. Structured interviews through questionnaires were conducted with te head of PKBM Assolahiyah and two facilitators to support the interpretive structural modelling (ISM) analysis. Meanwhile, field observations aimed to observe the CLC activities directly.

This research introduced ISM analysis as decision-making technique. With careful analysis, this paper provided some contributions to policy makers in CLC development. Supporting elements for CLC development were compiled from literature studies, interview results, and field observations. Each element was analyzed to structure its relationship. By using ISM, various elements that are not well-articulated 
can be transformed into a model that is well defined and visible structured.ISM is able to organize the number of information which is generated (Warfield, 2006:2).

Figure 1

Operational Stages of ISM Analysis

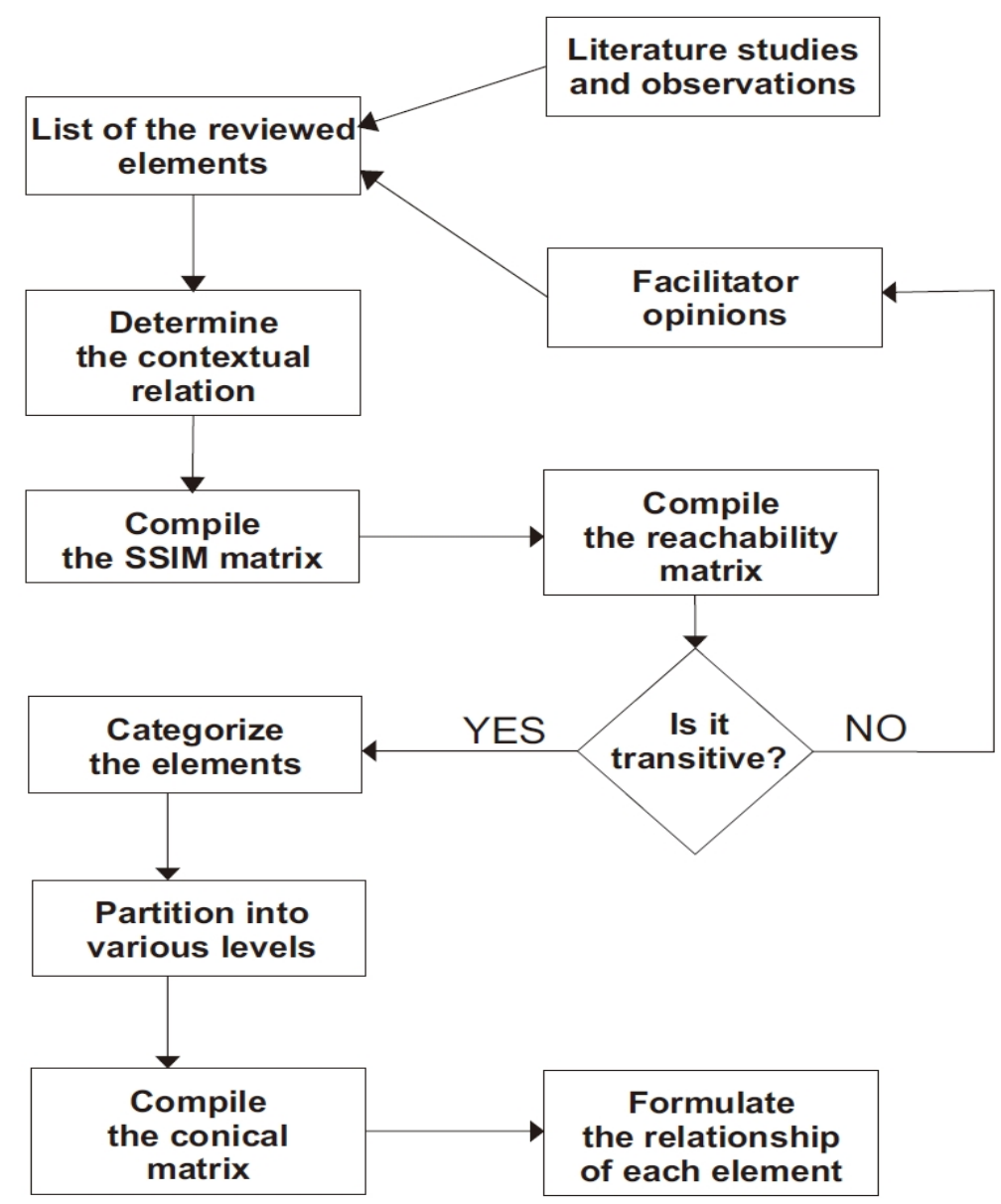

Figure 1 provides the operational stages of ISM analysis. Generally, Attri, Dev, \& Sharma (2013:3-6)explained six important steps of ISM analysis, i.e. (1) structural selfinteraction matrix (SSIM), (2) reachability matrix, (3) level partitions, (4)conical matrix, (5) digraph, and (6) ISM model. ISM analysis is comparative analysis of each element to determine the key element, structural relationship, and categorization. Each element was compiled in a pairwise matrix consisted of columns and rows. Facilitators gave their opinions in related to the importance level of each element.Symbol V means that element in row is more important than element in column. Symbol A means that element in column is more important than element in row. Symbol X means that two elements in each column and row have thesame importance. Symbol 0 means that two elements ineach column and row are not important.

Results from ISM analysis were referred to describe the policy of CLC development. The description was structured in a descriptive model that illustrates the policy support in accordance with CSR programs.

\section{BRIEF HISTORY OF PKBM ASSOLAHIYAH}

Based on interview results with the head of PKBM Assolahiyah (Heru Saleh), this CLC was initiated together with his friends in 2008. Because many children were dropped out from their schools, Heru and his friends tried to provide a learning opportunity to the children. Formerly, they taught English and computer skill. The learning process can be held in ricefields, beaches, houses, mosques, or other places.

In 2010, they started to concentrate the learning activities in a house that is a relic of 
Heru Saleh's parents. Because there was a permanent learning place, they can arrange a routine learning schedule. Besides literacy program, they have also provided an equality education in term of package $A, B$, and $C$ for dropped out people. Package $A$ is equal to elementary school, package $B$ is equal to junior high school, and package $C$ is equal to senior high school.

They have also provided an entrepreneurship program, such as shrimp processing, shrimp paste, sweets, and sewing courses. On February $13^{\text {th }}, 2014$, they got a financial support from PT Pertamina through CSR program to build the additional classrooms and renovate the CLC's building. They also got 24 units of the sewing machine. Since that time, they have been providing an early childhood education program (known as PAUD).

PKBM Assolahiyah has 16 teachers and tutors by developing the PAUD program, literacy, equality education, sewing courses, and economic entrepreneurship (such as the shrimp processing, shrimp paste, and sweets). The number of participants in PKBM Assolahiyah reached 80 people for PAUD program, 70 people for sewing courses, 20 people for literacy, 135 people for equality education, and 70 people for economic entrepreneurship.

Various achievements were received by PKBM Assolahiyah, such as the best CLC in Karawang District from the head of Education, Youth, and Sports Agency in 2013. The business group of PKBM Assolahiyah through economic entrepreneurship, especially for dried fish products, has also received a certificate of clean home industry for food product from the head of Karawang's Health Agencyin 2014.

\section{SUPPORT FOR THE CLC DEVELOPMENT}

Sustainability is an important parameter for the CLC success. It can be defined as the ability of CLC to perform their programs and activities continuously and to fulfill the local people needs (Dirbindikmas, 2012:9). Based on interview results, field observations, and literature reviews, to ensure the sustainability, CLC development is affected by five main factors, i.e. clear financial support, facility and infrastructure support, management capacity, teaching personnel capacity, and local leader participation. Each factor was elaborated in the following explanation.

\section{Operational cost of the CLC}

CLC performs programs and operational activities with financial support which could come from selffinancing, the government, corporations, work partners, etc. The operational cost includes honorarium, office stationery cost, the maintenance cost of CLC's facility and infrastructure, business capital, and other costs. The use of CLC's budget for operational activities must be effective, efficient, transparent, and accountable (Dirbindikmas, 2012:26). The importance of the operational cost was also suggested by Sharma (2014:96) and Sompong \& Rampai (2015:144).

\section{Physical facility and infrastructure}

Land that is equipped with buildings, classrooms, and equipment for supporting the learning process is an important requirement for a CLC. Any CLC was required to allocate the minimumland area of $150 \mathrm{~m}^{2}$, where 100 $\mathrm{m}^{2}$ of the area are for buildings and other facilities (Dirbindikmas, 2012:22-25). CLC's facilities and infrastructures can be provided by self-financing, the government, corporations, and other stakeholders. Infrastructure is one of the dominant factors in CLC development (Chitpin, 2014:218; Sompong \& Rampai, 2015:141) which requires support from various stakeholders(Sharma, 2014:96). The role of local community is also important to provide the infrastructure and facility for supporting the CLC activities (Hermawan \& Suryono, 2016:106).

\section{Management capacity}

The ability of planning, organizing, implementing, and controlling the CLC's programs and activities determines the CLC success. Therefore, CLC managers need to acquire the adequate management competencies. CLC is a center of community-based learning activities where initiatives, management and implementation are carried out by the community and assisted by their partners and facilitators (Rusdiana, 
2012:644). Certainly, the management capability of CLC managers should meet the problem and challenge characteristics in CLC development. The management capability determines the CLC success(Sharma, 2014:96; Rizka \& Tamba, 2015:10).

\section{Capacity building of teaching personnel}

Teaching personnelis an important component ensuring the quality of CLC participants according to their expectations and needs(Sharma, 2014:96). The teaching personnelis often termed as educators, tutors, instructors, or technical facilitators. They are directly responsible for the learning process or community empowerment and mostly come from the community members themselves or from the outside (Dirbindikmas, 2012:7).

\section{Participation of community leaders}

Certainly, the CLC existence requires the support from the local community leaders. Community leaders are one of the stakeholders that need to be involved in CLC development (Dirbindikmas, 2012:13). Their rolescould be directed to generate the motivation and participation of community members in CLC development, as well as strengthen the CLC existence as a media to improve the community capabilities and skills. Community leaders can also be facilitators for relevancy the CLC's programs with the community needs. The importance of community leaders involvement in CLC development was also suggested byMiradj \& Sumarno (2014:109).

\section{DEVELOPMENT POLICY OF PKBM ASSOLAHIYAH}

Support for the sustainability of PKBM Assolahiyah can be in the form of operational cost support for the CLC's activities, providing the physical facilities and infrastructures, building the management capacity, building the capacity of teaching personnel, and strengthening the role of community leaders. These supports were analyzed as important indicators for CLC sustainability. Based on interviews and document reviews, these supports were developed in more detail for the following elements: (1) operational cost support from regional government, (2) operational cost support from corporations, (3) operational cost support from the community, (4) facilities and infrastructuressupport from regional government, (5)facilities and infrastructures support from the corporations, (6) additional teaching personnel from external sources, (7) capacity building of teaching personnel, (8) capacity building of organizational management, (9) marketing support, and (10) the active role of local community leaders.

The above elements were analyzed their importance level based on the opinions from the community facilitators of PKBM Assolahiyah who are appointed by PT Pertamina (see Table 1). The facilitatorshavean ability to assess the priority level of those elements based on their experiences while they facilitated PKBM Assolahiyah. The results of the facilitator assessment may illustrate a priority policy that would be taken by policy makers in relation to the CLC development. Because a policy is a broad concept that encompasses many dimensions, we need to articulate various dimensions comprehensively in defining the concept of formulated policy (Torjman, 2005:4), including toformulate the CLC's policies. Therefore, the elements that are supportingthe CLC sustainability as formulated above were articulated to determine the key elements, relationship structures, and categorizations. For this purpose, the analytical instrument,like interpretive structural modeling (ISM), was used because ISMcan articulate those elements based on the opinions expressed by the facilitators. The ISM analysis produces the categorizations of each element, relationship structures, and key elements that illustrate the policy priorities in CLC development as described in detail through the following explanations.

\section{Elements Categorization}

The results of ISM analysis indicated that the elements of organizational management capacity improvement (element 8) and operational cost support from the community (element 3) are independent variables or driving factors, as shown in Figure 2. These 
variables can be key elements for CLC sustainability because the variables have high driving power and low dependence power.

Table 1

The Facilitator Assessment to the Importance Level of Each Element

\begin{tabular}{|c|c|c|c|c|c|c|c|c|c|c|}
\hline $\begin{array}{l}\text { Policy Elements to Support the Community Learning } \\
\text { Center }\end{array}$ & 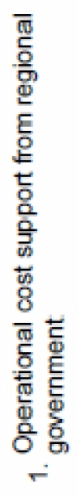 & 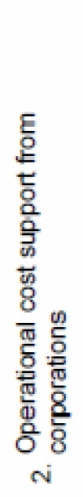 & 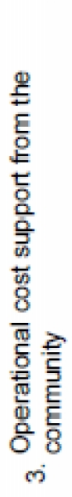 & 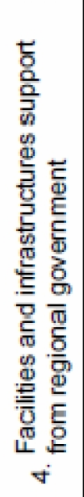 & 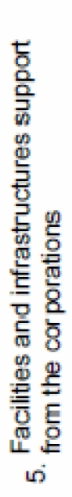 & 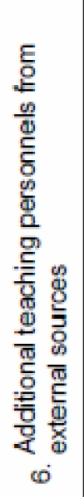 & 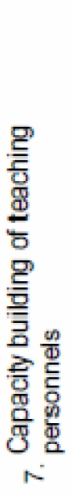 & 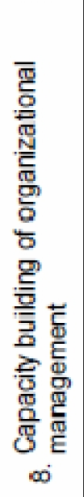 & 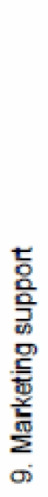 & 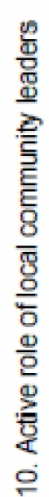 \\
\hline $\begin{array}{ll}\text { 1. } & \begin{array}{l}\text { Operational cost support from regional } \\
\text { government }\end{array} \\
\end{array}$ & & A & $\mathrm{v}$ & A & v & $x$ & A & A & $v$ & A \\
\hline 2. Operational cost support from corporations & v & & v & A & $x$ & A & A & A & V & A \\
\hline 3. Operational cost support from the community & A & A & & $\mathrm{v}$ & V & V & v & A & $\mathrm{v}$ & A \\
\hline $\begin{array}{l}\text { 4. Facilities and infrastructures support from } \\
\text { regional government }\end{array}$ & $\mathrm{v}$ & V & A & & A & V & V & v & $\mathrm{A}$ & $v$ \\
\hline $\begin{array}{l}\text { 5. Facilities and infrastructures support from the } \\
\text { corporations }\end{array}$ & A & $x$ & A & V & & A & A & A & $\mathrm{V}$ & $v$ \\
\hline $\begin{array}{l}\text { 6. Additional teaching personnels from external } \\
\text { sources }\end{array}$ & $x$ & $\mathrm{v}$ & A & A & V & & $\mathrm{x}$ & A & A & $v$ \\
\hline 7. Capacity building of teaching personnels & $\mathrm{v}$ & $\mathrm{v}$ & A & A & $v$ & $x$ & & A & $\mathrm{A}$ & A \\
\hline 8. Capacity building of organizational management & $\mathrm{v}$ & $\mathrm{v}$ & $\mathrm{v}$ & A & $v$ & $\mathrm{v}$ & v & & $\mathrm{v}$ & $\mathrm{v}$ \\
\hline 9. Marketing support & A & A & A & $\mathrm{v}$ & A & $\mathrm{v}$ & v & A & & $v$ \\
\hline 10. Active role of local community leaders & $\mathrm{v}$ & $\mathrm{v}$ & $\mathrm{v}$ & A & A & A & $\mathrm{v}$ & A & $\mathrm{A}$ & \\
\hline
\end{tabular}

Elements of operational cost support from regional government (element 1), operational cost support from corporations (element 2), and the capacity building ofteaching personnel (element 7) are dependent variables. It means that those variables depend on the concept and implementation of other elements. The facilitatorsargued that we should give more serious attention to the elements that are categorized as independent andlinkage to build community self-reliancethan the elements that are categorized as dependent.

Elements in the independent and linkage categories are more important elements than other elements. Elements in the independent category are the key elements (element 8 and element 3). Elements in the linkage category are the mutual relation in accordance with its importance, i.e. facilities and infrastructures support from regional government (element
4), marketing support (element 9), and the active role of community leaders (element 10). The facilities and infrastructures support from corporations (element 5) and additional teaching personnel from external sources (element 6) are also assessed to be related to the CLC sustainability, but its importance is lower than that of element 4, element 9 , and element 10.

\section{Relationship Structure of Each Element}

Figure 3 presents a relationship structure of each element according to its importance. The importance level of the elements starts from element 8 as a priority element that can be considered by policy makers in CLC development. However, each element can also influence CLC sustainability.

Elements 1 and 5 that are assessed by facilitatorshas lesser importance than the other elements. This assessment can 
occurbecause facilitators considered that the operational cost for the CLC managementhas been assisted by PT Pertamina and facilities and infrastructuressupport from the corporation is also adequately considered.

The facilitators assessed that it is important to encourage the operational costs support from the community (self-financing). This opinion can be understood because CLC is an institution which is come from, established by, developed for thecommunity. Consequently, the community support should always be optimized. In accordance with the optimal support from the community, it is certainly important to help the CLC participants and community by providing the market networks of CLC's products. It will increase the added value of the CLC's products and add the participant and community incomes, as well as, the community can obtain the benefit of CLC existence for improving their prosperity.

Figure2

\section{Element Categories that Affect the CLC} Sustainability

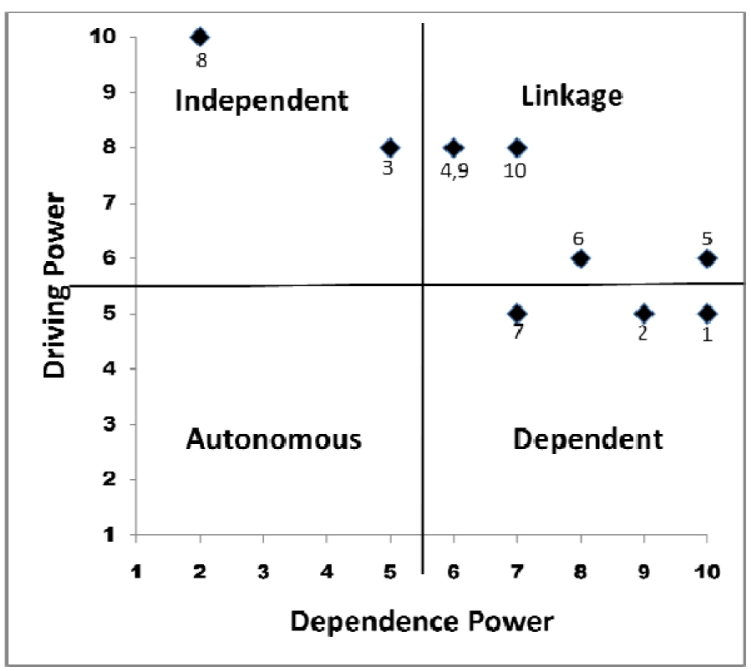

The interesting finding from the facilitator opinions was about the quality and quantity of teaching personnel. Facilitators placed the importance of the capacity building of teaching personnel under the element 8, element 3, element 9, element 4, and element 10. This opinion can be understood because, based on data from CLC manager, almost $45 \%$ of the teaching personnel hasgraduated their education at undergraduate level (bachelor's degree). The number of teachingpersonnel is also adequate with 16 teachers or tutors. This condition could indicate the power of human resources owned by PKBM Assolahiyah.

\section{Priority Policies and Implications for CSR Programs}

The categorization and relationship structure of each element showed that element 8is a key element. The improvement of organizational management capacity should be a policy priority that needs to be emphasized to ensure the CLC sustainability, although all elements also indicate the important roles to ensure the CLC sustainability. Capacity building of organizational management includes not only technical matters such as financial administration and program planning skills but also substantive matters in related to what the community and CLC institutions are trying to achieve (Pitchford \& Henderson, 2008:89).

Organizational management capacity refers to the ability of CLC managers to develop themselves to fulfill the community needs and expectations by managing their resources effectively, efficiently and accountable. Regards toWest (2009:105106), the required capacities of CLC managers in the CLC development toward self-reliance and sustainable institution in community empowerment are:

1. Able to develop short-term and longterm strategic plans,

2. Having volunteers and / or professionals with effective management and leadership skills,

3. Able to meet the required facilities and equipment,

4. Able to manage the financial resources and have adequate budget to implement the program,

5. Having an influential credibility for the institution,

6. Having a track record to achieve the tested results, and

7. Having a constituent base that can provide a political influence.

The capacity building of organizational management is expected to encourage and create the wide networks, as well as avoid the CLC managers who are too dependent on certain parties to strengthen the self-reliance ofCLC management. The networks consist of 
the community itself as major stakeholder and shareholder and involve the roles of other parties as contributive and corrective partners. Those partners provide the technical and financial assistances in accordance with substantive needs to build the community capacity and provide the corrective actions on program concepts and implementation. Partners could come from the government, corporations, NGOs, academics, etc.

Figure3

Relationship Structure of Each Element in CLC Development

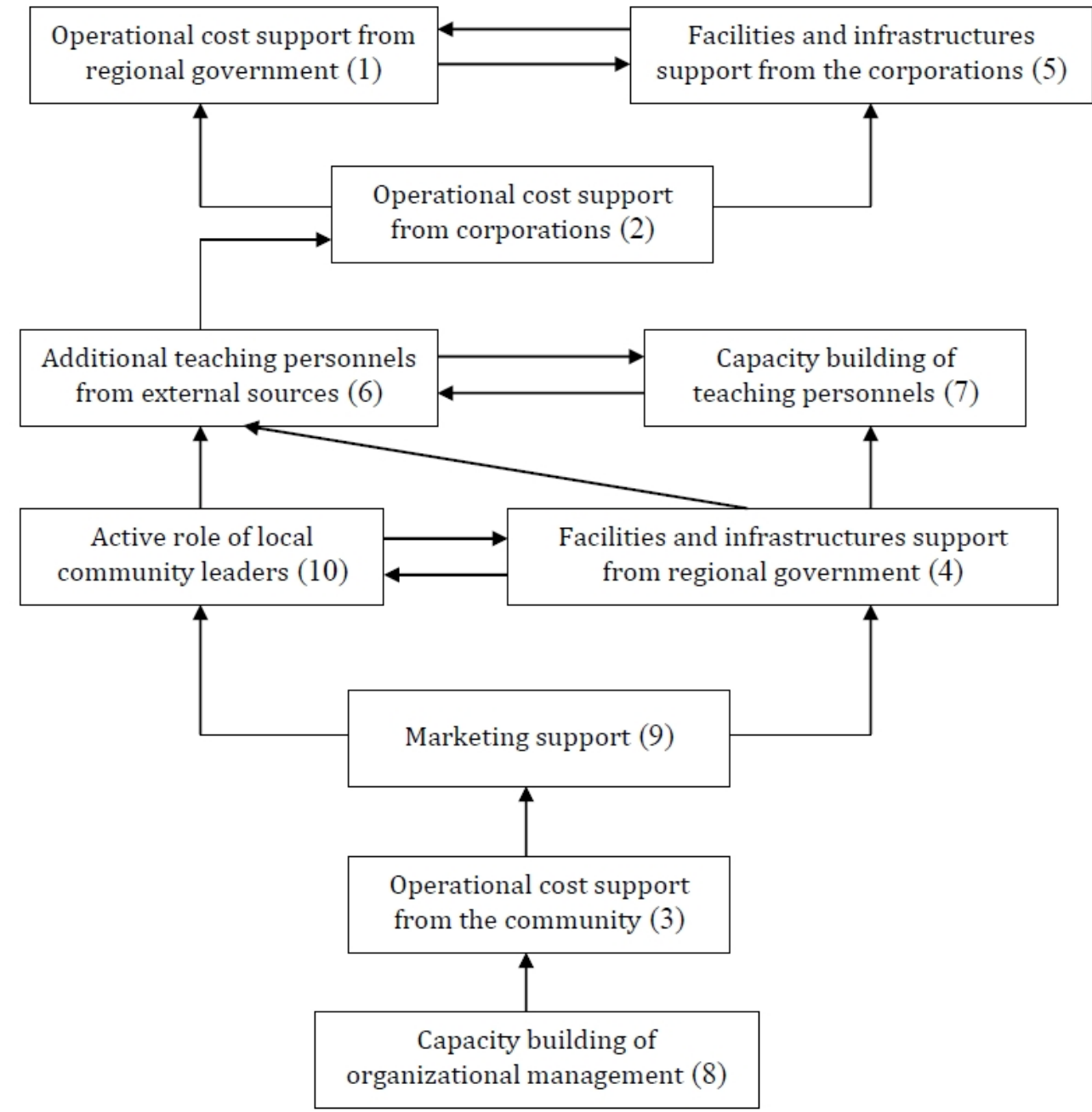

The government roles in the support forCLC sustainability have been regulated in the governmental legislation. However, it should be noted that the government should avoid determining the criteria and indicators of CLC management that can degrade the community self-reliance. For example, the provision of CLC accreditation should be intended to encourage self-reliance, or even sovereignty, of the community itself, rather than createthe negative interventions through the internalization of external values that do not comply with the socio-cultural characteristics of the community. Accreditation should serve as an effort to strengthen the community values that have been developed to ensure the CLC sustainability.

NGOs and academics can play a broader role in enhancing the management capacity of CLC managers to ensure its sustainability. NGOs couldemphasize their activities on institutional facilitation in accordance with the context of institutional problems faced by the community. Academicscould emphasize their activities on research and development to create the grassroot innovations that have comparative and competitive advantages.

The corporation roles could always be manifested in the form of CSR 
programs.However, CSR should not differ from the focus of government programs and should support the NGOs and academicsroles. Figure 4 illustrates how each policy to ensure the CLC sustainability. Regarding the definition made byRionda (2002:2), CSR should refer to transparent business practices based on ethical values, meet the legal requirements, and take into account the population, community, and environment, as well as include the community, government, corporations, academics, and NGOs. CLC development through CSR support should involve multi-stakeholder to implement their program.

The concept and implementation of CSR programs to support the CLC development should be understood as a form of program synergy between corporations, government, academics, and NGOs. Coordination and integration of the program could be conducted in accordance with their respective roles. CLC as a community institution must be able to contribute for improving the people's welfare and becominganinstitution that has an ability to build the networks with otherparties. In addition, PKBM as a non-formal education institution must have a policy space to correct the criteria and indicators applied by the government, in order to achieve the CLC self-reliance sustainability.

\section{CONCLUSION}

PKBM Assolahiyah is a CLC institution come from, established by, and developed for the community members in and around of Pasirjaya Village. This CLC has been developing for six years with the focus of the literacy program, equality education, early childhood education, sewing skills, and economic entrepreneurship. The CLC existence is useful for the community.

To ensure the CLC sustainability, there are ten elements that were considered. Those elements are: (1)operational cost support from regional government, (2) operational cost support from corporations, (3) operational cost support from the community, (4) facilities and infrastructures support from regional government, (5) facilities and infrastructures support from the corporations, (6) additional teaching personnel from external sources, (7) capacity building of teaching personnel, (8) capacity building of organizational management, (9) marketing support, and (10) the active role of local community leaders. Based on the ISM analysis, the key element that could be prioritized in ensuring the CLC sustainability is capacity building of organizational management.

The capacity building of organizational management becomes a focus in the policy model of CLC development. The model is expected to improve the community ability as major stakeholder and shareholder in establishing networks with other parties as contributive and corrective partners. Partners can come from the government, corporations, NGOs, academics, etc. Therefore, the initiation of CSR programs should be developed within a policy framework that strengthens the role of the parties to improve the community capacity in general and CLC managers in particular. The policy of each stakeholder should be a whole of CSR program and directed to strengthen the CLC management. The policy should also provide a policy space for corrective actions, in order to ensure the CLC self-reliance and sustainability.

\section{REFERENCES}

Attri, R., Dev, N., \& Sharma, V. (2013). Interpretive structural modelling (ISM) approach: An overview. Research Journal of Management Sciences, 2(2), 38. https://doi.org/10.1108/01443579410 062086

Chitpin, S. (2014). Principals and the professional learning community: Learning to mobilize knowledge. International Journal of Educational Management, 28(2), 215-229. https://doi.org/10.1108/IJEM-04-20130044

Dirbindikmas. (2012). Standar dan Prosedur Penyelenggaraan Pusat Kegiatan Belajar Masyarakat (PKBM). Jakarta: Kementerian Pendidikan dan Kebudayaan. https://doi.org/10.1007/s13398-0140173-7.2

Herlina, Y., Oktavia, D. A., \& Elvawati. (2014). Pelaksanaan program corporate social responsibility (CSR) PT. Visi Utama 
Mandiri (VUM) di Jorong Sungai Kunyit, Kab. Solok Selatan. Jurnal Ilmu Sosial Mamangan, III(1), 10-17.

Hermawan, Y., \& Suryono, Y. (2016). Partisipasi masyarakat dalam penyelenggaraan program-program pusat kegiatan belajar masyarakat Ngudi Kapinteran. Jurnal Pendidikan Dan Pemberdayaan Masyarakat, 3(1), 97-108. https://doi.org/10.21831/jppm.v3i1.55 94

Miradj, S., \& Sumarno. (2014). Pemberdayaan masyarakat miskin melalui proses pendidikan non formal, upaya meningkatkan kesejahteraan sosial di Kabupaten Halmahera Barat. Jurnal Pendidikan Dan Pemberdayaan Masyarakat, 1(1), 101-112.

Pitchford, M., \& Henderson, P. (2008). Making Spaces for Community Development. Bristol: The Policy Press.

Rionda, Z. I. (2002). What is Corporate Social Responsibility? Washington DC: Catalyst Consortium.

Rizka, M. A., \& Tamba, W. (2015). Pemetaan inovasi program pendidikan non formal pada pusat kegiatan belajar masyarakat (PKBM) di Kota Mataram. Jurnal Transformasi, 1(1), 1-10.

Rusdiana, A. (2012). Utilizing community through developing the center of community's learning activity ( CCLA) in the rural area, 2(4), 641-645. Sharma, T. N. (2014). Education for rural transformation: The role of community learning centers in Nepal. Journal of Education and Research, 4(2), 87-101. https://doi.org/10.3126/jer.v4i2.11043

Sompong, N., \& Rampai, N. (2015). The development model of knowledge management to strengthen thai ict community learning center. Procedia Social and Behavioral Sciences, 176, 139147.

https://doi.org/10.1016/j.sbspro.2015. 01.454

Torjman, S. (2005). What is Policy? Ottawa: The Caledon Institute of Social Policy. Retrieved from http://vibrantcanada.ca/files/what_is_p olicy.pdf

UNESCO. (2008). Community Learning Centres: Country Reports from Asia. Bangkok: UNESCO. Retrieved from http://unesdoc.unesco.org/images/001 6/001604/160492e.pdf

UNESCO. (2011). Sustainability of Community Learning Centres: Community Ownership and Support. Bangkok: UNESCO.

Warfield, J. N. (2006). An Introduction To Systems Science. Singapura: World Scientific Publishing Co. Pte. Ltd.

West, M. (2009). Establishing Communitybased Organizations. In R. Phillips \& R. H. Pittman (Eds.), An Introduction to Community Development (pp. 104-118). New York: Routledge. https://doi.org/10.1017/CB097811074 15324.004 